\title{
What Have We Learned of Asian Crisis?
}

\author{
Rim Mekki* \\ Higher Institute of Management of Sousse, University of Sousse, Tunisia
}

\author{
DOI: $\underline{10.36348 / \text { sjef.2019.v03i11.002 }}$ \\ | Received: 02.11.2019 | Accepted: 09.11.2019 | Published: 18.11.2019 \\ *Corresponding author: Rim Mekki
}

\section{Abstract}

During the eighties and the beginning of the nineties, several countries experienced serious banking crises. Such proliferation of the problems of the large-scale banking sector has caused widespread concern. Indeed, banking crises undermine the functioning of the financial system and the economy in general. Most countries have tried to underpin the consequences of banking crises through various types of intervention ranging from the pursuit of accommodative monetary policy to the bailout of insolvent financial institutions with public funds. However, even when carefully designed, rescue operations have several disadvantages. The purpose of this paper is to assess the regulatory environment of banks, a decade after the Asian crisis. We will identify the factors relating to banking supervision contributing to the triggering of crises in emerging countries in the years 1990s and see if the countries have improved their regulation in 2007 and which coincided with the subprime crisis. For this, we have studied a sample of 105 developed and emerging countries over two years, 1997 and 2007.

Keyswords: financial liberalization, banking crisis, Logit, supervision, financial stability.

Copyright @ 2019: This is an open-access article distributed under the terms of the Creative Commons Attribution license which permits unrestricted use, distribution, and reproduction in any medium for non-commercial use (NonCommercial, or CC-BY-NC) provided the original author and source are credited.

\section{INTRODUCTION}

The literature on regulation and its effects on the economies of countries present mixed reviews. Some studies have concluded that good regulations enhance financial development and contributes to economic stability [1].Others have found that strong regulations can lead to banking crises over the decades [2]. This divergence of results can be explained by several reasons. Egan et al. [3-7]. Explain the negative influence of deposit insurance on the emergence of crises by the fact that the shareholders of a bank can benefit from the "deposit insurance subsidy" by increasing the leverage and risk of the deposit insurance bank, which can lead to the appearance of crises.

For example Mathonnat et al. [8] Angkinand et al. [3], Allen et al. [1], state that countries characterized by deteriorating macroeconomic factors such as GDP growth, interest rate, inflation, as well as capital flows are the most affected by banking crises. Crises can also be explained by the instability of the banking environment. In fact supervisors face several structural obstacles, such as the lack of transparency of information on financial system conditions due to the weakness of accounting and auditing standards [2]. In addition, the assessment of banking risks by the banks and their supervisors is not obvious given the low qualification of the teams. Credit risk assessment is conditioned by good information on borrowers that does not exist in the banking sector [9].On the other hand, banking crises are the consequences of slippages, corruption, non-compliance with laws, and the unreliability of regulatory corrective actions $[10,11]$, Klapper and al.[12].

This overview of the literature reveals that there is a real need to determine the factors that triggered the crises of the years 1997 and to verify if these same factors have improved and could confront the crisis of the subprimes. To do this, we have analyzed the impact of macroeconomic, institutional, and regulatory factors on the emergence of banking crises during the Asian crisis and during the subprime crisis. In fact, several countries have tightened capital rules and improved surveillance policy following the Asian crisis, but these reforms have not improved the stability and efficiency of banks.

Our results suggest that restrictions on insurance, the financial market, and the real estate sector are unrelated to the outbreak of banking crises in all our estimates. This leaves us to affirm that a good regulation leads to a banking stability. On the other hand, the regulation on the banking activity to hold nonfinancial companies has increased bank fragility. We can conclude that the banks that diversify their activities 
will be able to widen their sources of income and become more resistant to shocks. This will have positive effects on the stability of the banking system.

Our work is structured around seven sections: a presentation of the elements of banking regulation (2), Bank risk taking (3), Entry of foreign banks (4) a empirical study (5) an interpretation of the results at the section (6) and the last section is devoted to the conclusion (7).

\section{The Role of Banking Regulations}

Prudential regulations aim to protect the banking system from all problems. Its purpose is to have a mix of transaction tracking with respect to capital requirements, entry restrictions for foreign banks, and restrictions on bank activity.

\section{The Regulation of Own Funds}

The regulation of own funds represents the funds that banks must hold as reserves with the central bank. These regulations are imposed by Basel's international standards. Cubillas et al. [13] analyze a sample of 4333 banks from 82 countries over the period stretching from 1991 to 2007 . They find that capital requirements help reduce the negative impact of financial liberalization on the financial stability of both developed and developing countries. Indeed, the negative influence of the financial liberalization becomes positive in both groups of countries if the regulation of capital is respected. With the same idea Brinkmann and Horvitz [9] also find evidence of significant responses of credit supply to Basel I capital requirements. Wagster [14] reaches the same conclusion for Canada and the United Kingdom. It does not find support for this result in the cases of Germany, Japan, and the United States.

\section{The Regulation of Market Discipline}

The Basel II agreements explicitly insist on capital requirements (Pillar 1), formal supervision (Pillar 2) and strengthening of market discipline (Pillar 3 ) as tools to improve the stability of banks. Indeed, the aim of the Basel 2 reform is to better integrate the increased complexity of the banking business while leaving financial institutions certain autonomy in the choice of possible options to define the minimum capital required for the coverage of potential losses [15].

\section{Banking Risk Taking}

Financial liberalization was marked by weak banking supervision which encouraged the banking sector to take risks in order to ensure more profit. Lassoued et al. [16] have studied the impact of foreign and state ownership on bank risk. The authors analyzed panel data applied to a sample of 171 commercial banks in the MENA region using a least squares regression over the period 2006-2012. Findings show that state ownership encourages banks to take more risks. In addition, state-owned banks tend to increase the solvency ratio to guard against a high level of risk. They have also found that all classes of shareholders are adopting a cautious attitude that influences risk reduction after the 2008 crisis. Lassoued et al. [16] point out that the ownership structure is a corporate governance mechanism that affects banks' risk taking in emerging markets.

In addition, Amri et al. [1] have studied the importance of surveillance, in the presence of financial liberalization and its relationship with the financial crisis using a Probit mode ${ }^{1}\left[{ }^{1}\right]$.Thus, they took a sample of 65 developing countries from 1976 to 2005. They have reached the conclusion that financial liberalization leads to financial fragility as a result of excessive risktaking.

\section{Entry of Foreign Banks}

The findings on the role of foreign banks and their impact on the host country's economy are mixed. For some, these banks play an important role in improving efficiency and competition. For others they constitute an indirect channel for spreading the crisis. Indeed, Baicu [17] finds that foreign banks have led to an increase in foreign currency liabilities, external debt and foreign currency borrowings before the crisis in Romania. Moreover all these factors have increased the vulnerability of Romania accompanied by strong regulation according to international standards.

Chen et al. [18] find that the entry of foreign banks increases competition in banking systems. In fact, following the global recession of 2008-2009, Latin American countries seem to benefit more from the penetration of foreign banks than emerging markets in Asia.

\section{Empirical Study}

The objective of this work is to analyze the determinants of banking crises. To achieve this, we will study a sample of 105 countries in 2 cross-sectional studies in 1997 and 2007. We have chosen to model the determinants of bank crises using the logit model that appears to be most used in economic studies. The logistic regression is based on the assumption of a latent, unobserved variable $y_{i}^{*}$ that shows a specific outcome that can be observed empirically as a dichotomous variable $y_{i}$. In our case, $y_{i}$ is the CRISES' variable which measures the on sand of crises in a sand of countries? It takes the value 1 if $y_{i}^{*}$ exceeds a threshold value $\tau$. In logistic regression $\tau=0$ by assumption. The latent variable can be expressed in a linear model:

\footnotetext{
1. In statistics and econometrics, the probit model represents a binomial regression model. this model was introduced in 1934 it represents a special case of the generalized linear model
} 


$$
y_{i}^{*}=x_{i}^{\prime} \beta+\varepsilon_{i}(1)
$$

The explanatory variables, $x_{i}$, used to model bank crises relate to macroeconomic factors, institutional factors and regulatory factors. Taking into consideration what we mentioned, the objective of this modelling is to provide a response to our problem relating to the impact of regulatory, banking and institutional factors on the occurrence of crises. In order to derive the probability, we start by assuming the threshold mentioned above $(\tau=0)$ and set up the equation:

$$
p\left(y_{i}=1 \mid x_{i}\right)=p\left(y_{i}^{*}>\tau\right)=p\left(y_{i}^{*}>0\right)
$$

Substituting equation (1) leads to

$$
p\left(y_{i}=1 \mid x_{i}\right)=p\left(x_{i}^{\prime} \beta+\varepsilon_{i}>0\right)
$$

Rearranging the right-hand side of the equation leads to $p\left(y_{i}=1 \mid x_{i}\right)=p\left(\varepsilon_{i}>-x_{i}^{\prime} \beta\right)=p\left(\varepsilon_{i} \leq x_{i}^{\prime} \beta\right)$ (4)

The right-hand side of the equation describes the probability of being smaller or equal to a specific value. This kind of probability is given by a cumulative probability density function (CDF), noted by $G($.$) and$ we can write

$$
p\left(y_{i}=1 \mid x_{i}\right)=p\left(\varepsilon_{i} \leq x_{i}^{\prime} \beta\right)=G\left(x_{i}^{\prime} \beta\right)
$$

In logistic regression it is assumed that the errors follow a logistic distribution with expectation $E\left(\varepsilon_{i}\right)=0$ and variance $v\left(\varepsilon_{i}\right)=\pi^{2} / 3$. We can write

$$
p\left(y_{i}=1 \mid x_{i}\right)=\frac{\exp \left(x_{i}^{\prime} \beta\right)}{1+\exp \left(x_{i}^{\prime} \beta\right)}(6)
$$

Therefore,

the

conditional probability $p\left(y_{i}=1 \mid x_{i}\right)$ measures the probability of having a crisis given exogenous variables. The coefficient $\beta$ is the marginal effect measure on the conditional probability when there is unit change in data $x_{i}$. The estimator $\hat{\beta}$ could be calculated through maximizing the following log-likelihood function.

$$
\ln L=l=\sum_{i=1}^{n}\left[y_{i} \ln G\left(x_{i}^{\prime} \beta\right)+\left(1-y_{i}\right) \ln \left(1-G\left(x_{i}^{\prime} \beta\right)\right)\right]
$$

Using CRISES, the variable to be explained indicating whether or not there is an outbreak of crises and $i$ represents each country in the sample.A detailed description of the variables selected for our econometric study will be presented below.

\section{Presentation of Data}

To analyze the decisive effects of banking crises. The variables selected relate to supervision indicators and banking regulations, macroeconomic and institutional factors. Our study is based on a sample of 105 developed and developing countries presented in Appendix 1, and in 1997, the triggering period for emerging market crises and 2007, and the triggering period for the subprime crisis. Our choice of explanatory variables reflects the theory, the availability of data, and the determinants of bank crises summarized in the previous sections. In addition, for the construction of the dummy bank crisis variable, we identified and dated distress episodes of the banking sector in both the 1997 and 2007 periods using mainly the database of Laeven and Valencia [19]. The explanatory variables are presented in the following table hereafter.

\section{6-Interpretation of Results \\ Macroeconomic Variables}

The results of the regressions show that the weak GDP growth for the year 2007 is clearly associated with a high probability of a banking crisis. This confirms that shocks to the economy have been a major source of systemic problems in the banking sector in the years 2007. However, the variable measuring growth is not significant in 1997.For Thakor, A [20] to achieve financial stability and growth, it is necessary to increase the capital requirements in order to reduce solvency risk.

Moreover, the coefficient of the credit variable is positive, and highly significant in the year 1997.This is consistent with the results of Dong-EunRhee et al. [21] which have concluded that the expansion of domestic credit increases banking crises. As an indicator of the vulnerability of the financial system, the ratio of M2 to foreign exchange reserves of the central bank does not seem to increase the probability of crises in our model in 1997. Indeed, this ratio is significant in 2007, which leaves us to conclude that the growth of the commitments, not covered of the banking sector, was one of the causes of triggering banking crises in 2007.

As for the variable measuring the banking development "credit to the private sector" is not significant in 2007 but it explains the crises in 1997. It seems that supervision was stronger in 2007. What joins the results, from Demirguc Kunt, et al. [22], who suggest that regulatory and supervisory policies of banks that encourage private sector control improve the efficiency of banks.

\section{Institutional Variables}

Nos estimations ont montré que la variable loi présente un effet significativement négatif sur les deux périodes. Ce qui montre que les crises se sont apparues dans les pays qui ne respectent pas la loi. Pour la variable mesurant la Corruption et contrairement à nos attentes, elle ne présente pas un coefficient significatif pour les deux sections.

Our ratings have demonstrated that the law variable presents a significantly negative effect on both periods. This shows that crises have emerged in countries which do not respect the law. For the variable 
measuring the corruption, unlike our expectations, it does not display a significant coefficient for both sections.

\section{Regulatory Variables}

The variable $\mathrm{z}$ score is significantly negative. This shows that the higher the banking risk, the more banking crises are expected. Thus, the instability of banks has a significant effect on the appearance of banking crises. As for the concentration of the big five banks, our results have shown that there is no clear correlation between concentration levels and the crisis for both dates. Indeed, concentration reduces banking competition, thus having a positive effect on banking stability. Our findings are consistent with those of Fosu et al. [26]

Loss of unrealized securities shows a positive sign in 1997.Indeed, banks are allowed to intervene in a number of activities and may engage in companies that may be sub-optimal for investors [23], which confirm our results. Our results lead us to conclude that restrictions on insurance, the financial market, and the real estate sector were unrelated to the outbreak of banking crises in all our estimates. Indeed the size of some banks makes them difficult to monitor. Moreover, such banks can become so powerful politically and economically that they become « too big too fail » [24].

The coefficient of the variable measuring the exchange rate loss is significantly positive in 1997.It seems that an imbalance in the stock of exchange favors can trigger a banking crisis. Our results confirm the work of Kaminsky and Reinhart [25] who find that 56\% of banking crises have been accompanied by currency crises within three years; with a percentage of $24 \%$ shifted by one year or less between the two crises, named by the authors by "twin crisis". The authors do not conclude that there is a unidirectional causal link between banking crises and currency crises.

In addition, the variable measuring the number of rejected foreign banking license applications positively and significantly affects the emergence of banking crises in 1997 in emerging countries.

This shows that the banking system of countries affected by the crisis was not open internationally. The fact that banks do not engage in new technologies will increase the bank risk and consequently the banking crises.

Table-1: The explanatory variables

\begin{tabular}{|c|c|c|}
\hline Variables codes & Variables & Source \\
\hline \multicolumn{3}{|c|}{ Bank macroeconomicfactors } \\
\hline Growth & GDP Growthannual \% & World Bank \\
\hline Inflation & Inflation GDP déflatorannual \% & World Bank \\
\hline Crédit & Credit provided for the private sector as a percentage of GDP. & World Bank \\
\hline M2_reserve & M2 ratio to foreign exchange reserves & World Bank \\
\hline Debdt & Doubtfuldebts & World Bank \\
\hline \multicolumn{3}{|c|}{ Institutional Indicators } \\
\hline Rule of low & Index that measures compliance with contracts & World Bank \\
\hline Corruption & Measuring the transparency of banks & World Bank \\
\hline \multicolumn{3}{|c|}{$\begin{array}{l}\text { Indicators of Supervision and Banking Regulations } \\
\end{array}$} \\
\hline $\begin{array}{l}\text { regulatory barriers for } \\
\text { banks that }\end{array}$ & $\begin{array}{l}\text { Stock market activities, Insurance activities, Real estate activities and } \\
\text { Ownership of non-financial enterprises }\end{array}$ & Barth et al. [2] \\
\hline Concentration & the 5-bank concentration ratio & Barth et al. [2] \\
\hline Z_score & Banking risk measurement & Bankscoope \\
\hline insurance & Deposit insurance & $\begin{array}{l}\text { Demirguc-Kunt et al. } \\
\text { [22]. }\end{array}$ \\
\hline losses/loan & Market value of loan losses & Barth et al. [2] \\
\hline losses/exchange & Unrealized foreign exchange losses & Barth et al. [2]. \\
\hline $\begin{array}{l}\mathrm{Nb} \text { of foreign } \\
\text { applications }\end{array}$ & Number of foreign applications for banking licenses & Barth et al. [2]. \\
\hline $\begin{array}{l}\text { Nb of domestic } \\
\text { applications }\end{array}$ & Number of domestic applications for banking licenses & Barth et al. [2] \\
\hline
\end{tabular}


Table-2: Estimation results for all emerging and developed countries in 1997

\begin{tabular}{|c|c|c|c|c|c|c|}
\hline Variables & $\begin{array}{c}\text { Spécification } \\
\text { (1) }\end{array}$ & $\begin{array}{c}\text { Spécification } \\
\text { (2) }\end{array}$ & $\begin{array}{c}\text { Spécification } \\
\text { (3) }\end{array}$ & $\begin{array}{c}\text { Spécification } \\
\text { (4) }\end{array}$ & $\begin{array}{c}\text { Spécification } \\
(5)\end{array}$ & $\begin{array}{c}\text { Spécification } \\
\text { (6) }\end{array}$ \\
\hline \multirow[t]{2}{*}{ Growth } & 0,055 & & 0,096 & 0,079 & 0,044 & \\
\hline & $(0,046)$ & & $(0,073)$ & $(0,061)$ & $(0,069)$ & \\
\hline \multirow[t]{2}{*}{ Inflation } & 0,008 & & 0,004 & $0,004 *$ & $0,005^{*}$ & \\
\hline & $(0,011)$ & & $(0,005)$ & $(0,002)$ & $(0,003)$ & \\
\hline \multirow[t]{2}{*}{ Credit } & 0,007 & & $0,029 * *$ & $0,031 * * *$ & $0,039 * * *$ & $0,042 * * *$ \\
\hline & $(0,008)$ & & $(0,012)$ & $(0,008)$ & $(0,011)$ & $(0,016)$ \\
\hline \multirow[t]{2}{*}{ M2_reserve } & $-0,071$ & & $-0,058$ & $-0,067$ & $-0,079$ & $-0,115$ \\
\hline & $(0,056)$ & & $(0,067)$ & $(0,053)$ & $(0,053)$ & $(0,093)$ \\
\hline \multirow[t]{2}{*}{ debt } & 0,021 & & $0,057 * *$ & 0,025 & 0,029 & 0,028 \\
\hline & $(0,014)$ & & $(0,026)$ & $(0,018)$ & $(0,026)$ & $(0,023)$ \\
\hline \multirow[t]{2}{*}{ Bank_Zscore } & & $-0,053$ & $-0,083^{* *}$ & $-0,075^{*}$ & $-0,083$ & $-0,114 * *$ \\
\hline & & $(0,035)$ & $(0,038)$ & $(0,039)$ & $(0,054)$ & $(0,054)$ \\
\hline \multirow[t]{2}{*}{ Rule Law } & & & $-1,529 * * *$ & $-1,421 * * *$ & $-2,031 * * *$ & $-2,117 * * *$ \\
\hline & & & $(0,435)$ & $(0,428)$ & $(0,459)$ & $(0,501)$ \\
\hline \multirow[t]{2}{*}{ Security } & & & & 0,026 & 0,016 & 0,297 \\
\hline & & & & $(0,306)$ & $(0,334)$ & $(0,415)$ \\
\hline \multirow[t]{2}{*}{ insurance } & & & & 0,172 & $-0,160$ & $-0,011$ \\
\hline & & & & $(0,281)$ & $(0,255)$ & $(0,312)$ \\
\hline \multirow[t]{2}{*}{ Real Estate } & & & & 0,054 & 0,386 & \\
\hline & & & & $(0,278)$ & $(0,282)$ & \\
\hline \multirow[t]{2}{*}{$\begin{array}{l}\text { Non-financial } \\
\text { firms }\end{array}$} & & & & $-0,648 * *$ & $-0,826 * *$ & $-0,744^{*}$ \\
\hline & & & & $(0,626)$ & $(1,252)$ & $(0,703)$ \\
\hline \multirow[t]{2}{*}{ Corruption } & & & 0,468 & & & \\
\hline & & & $(0,333)$ & & & \\
\hline \multirow[t]{2}{*}{ Loss/Loans } & & & & & $-0,344$ & $-1,122$ \\
\hline & & & & & $(0,610)$ & $(0,755)$ \\
\hline \multirow[t]{2}{*}{ Loss/exchange } & & & & & $1,593 * * *$ & 0,811 \\
\hline & & & & & $(0,615)$ & $(0,778)$ \\
\hline \multirow[t]{2}{*}{ Concentration } & & & & & & $-0,007$ \\
\hline & & & & & & $(0,010)$ \\
\hline \multirow[t]{2}{*}{$\begin{array}{l}\mathrm{Nb} \text { of foreign } \\
\text { applications }\end{array}$} & & & & & & $-0,021$ \\
\hline & & & & & & $(0,034)$ \\
\hline \multirow[t]{2}{*}{ Refused } & & & & & & $0,251^{*}$ \\
\hline & & & & & & $(0,151)$ \\
\hline \multirow[t]{2}{*}{ Loss/share } & & & & & & $0,011 * *$ \\
\hline & & & & & & $(0,902)$ \\
\hline \multirow[t]{2}{*}{ Constant } & $-1,136 * *$ & 1,893 & 1,147 & 0,588 & $-0,308$ & 0,523 \\
\hline & $(0,500)$ & $(1,756)$ & $(2,072)$ & $(1,297)$ & $(1,651)$ & $(1,739)$ \\
\hline Observations & 105 & 105 & 100 & 102 & 102 & 98 \\
\hline & & & & & & \\
\hline
\end{tabular}

Standard errors in parentheses

$* * * \mathrm{p}<0.01, * * \mathrm{p}<0.05, * \mathrm{p}<0.1$ 
Table-3: Estimation results for both groups of countries (emerging and developed) in 2007

\begin{tabular}{|c|c|c|c|c|c|c|}
\hline Variables & Spécification(1) & $\begin{array}{c}\text { Spécification } \\
\text { (2) }\end{array}$ & $\begin{array}{c}\text { Spécification } \\
\text { (3) }\end{array}$ & $\begin{array}{c}\text { Spécification } \\
(4)\end{array}$ & $\begin{array}{c}\text { Spécification } \\
(5)\end{array}$ & $\begin{array}{c}\text { Spécification } \\
(6)\end{array}$ \\
\hline \multirow[t]{2}{*}{ Growth } & $0,141^{*}$ & & $0,182 * *$ & $0,200 * *$ & $0,172 * *$ & \\
\hline & $(0,078)$ & & $(0,086)$ & $(0,082)$ & $(0,084)$ & \\
\hline \multirow[t]{2}{*}{ Inflation } & $-0,014$ & & $-0,066$ & $-0,062$ & $-0,023$ & \\
\hline & $(0,054)$ & & $(0,064)$ & $(0,058)$ & $(0,084)$ & \\
\hline \multirow[t]{2}{*}{ Credit } & $-0,008$ & & $-0,002$ & $-0,002$ & $-0,004$ & $-0,010$ \\
\hline & $(0,006)$ & & $(0,007)$ & $(0,007)$ & $(0,006)$ & $(0,007)$ \\
\hline \multirow[t]{2}{*}{ M2_reserve } & $0,083^{*}$ & & 0,0821 & $0,091 * *$ & $0,128 * *$ & 0,129 \\
\hline & $(0,047)$ & & $(0,068)$ & $(0,040)$ & $(0,063)$ & $(0,080)$ \\
\hline \multirow[t]{3}{*}{ Creance } & $0,038 * *$ & & $0,079 * * *$ & $0,066 * * *$ & $0,054 * *$ & $0,0318^{*}$ \\
\hline & $(0,017)$ & & $(0,029)$ & $(0,024)$ & $(0,022)$ & $(0,017)$ \\
\hline & & $(0,028)$ & & & & \\
\hline \multirow[t]{2}{*}{ bank_zscore } & & $-0,074 * *$ & $-0,088 * *$ & $-0,083 * *$ & $-0,0759 * *$ & $-0,0719 *$ \\
\hline & & $(0,036)$ & $(0,041)$ & $(0,038)$ & $(0,037)$ & $(0,041)$ \\
\hline \multirow[t]{2}{*}{ Law } & & & $-0,960$ & $-0,308$ & $-0,376$ & $-0,254$ \\
\hline & & & $(0,994)$ & $(0,348)$ & $(0,366)$ & $(0,363)$ \\
\hline \multirow[t]{2}{*}{ securities } & & & & & 0.0772 & 0.974 \\
\hline & & & & & $(0.604)$ & $(1.030)$ \\
\hline \multirow[t]{2}{*}{ Insurance } & & & & & 0.867 & 1.018 \\
\hline & & & & & $(0.724)$ & $(0.756)$ \\
\hline \multirow[t]{2}{*}{ Real Estate } & & & & & -0.266 & -0.864 \\
\hline & & & & & $(0.579)$ & $(0.686)$ \\
\hline \multirow[t]{2}{*}{ Non-financial firms } & & & & & 0.0772 & 0.974 \\
\hline & & & & & $(0.604)$ & $(1.030)$ \\
\hline \multirow[t]{2}{*}{ Corruption } & & & 0,366 & & & \\
\hline & & & $(0,958)$ & & & \\
\hline \multirow[t]{2}{*}{ Loss/ Loan } & & & & & $-0,266$ & $-0,864$ \\
\hline & & & & & $(0,579)$ & $(0,686)$ \\
\hline \multirow[t]{2}{*}{ Loss/Change } & & & & & 0,077 & 0,974 \\
\hline & & & & & $(0,604)$ & $(1,030)$ \\
\hline \multirow[t]{2}{*}{ Concentration } & & & & & & $-0,0463$ \\
\hline & & & & & & $(0,866)$ \\
\hline \multirow[t]{2}{*}{$\begin{array}{l}\mathrm{Nb} \text { of foreign } \\
\text { applications }\end{array}$} & & & & & & $0,416^{*}$ \\
\hline & & & & & & $(0,221)$ \\
\hline \multirow[t]{2}{*}{ refused } & & & & & & $-0,422$ \\
\hline & & & & & & $(0,281)$ \\
\hline \multirow[t]{2}{*}{ Loss/share } & & & & & & $-1,014$ \\
\hline & & & & & & $(1,067)$ \\
\hline \multirow[t]{2}{*}{ Constant } & $-1,333$ & $-1,428$ & $-0,019$ & 0,187 & $-0,092$ & 1,397 \\
\hline & $(0,840)$ & $(3,936)$ & $(1,112)$ & $(0,947)$ & $(1,156)$ & $(1,088)$ \\
\hline Observations & 105 & 84 & 84 & 101 & 89 & 89 \\
\hline
\end{tabular}

Standard errors in parentheses

$$
* * * \mathrm{p}<0.01, * * \mathrm{p}<0.05, * \mathrm{p}<0.1
$$

The ability of banks to own and control nonfinancial enterprises increases the fragility of banks in 1997.According to our results; many countries have allowed cross-ownership of shares between banks and non-financial companies. As a result, the regulation on the extent to which a bank may hold shares in a nonfinancial corporation has affected a bank's ability to diversify its sources of revenue. Consequently, the absence of diversification has clearly led banks to bank fragility and consequently to a banking crisis.

As a result, we can see that supervision and regulation of capital have not been enough to completely prevent banks from increasing their risk taking. On the contrary, banks are more restricted in terms of activities than they were allowed to do while less likely to take more risks. In the same ideas, Barth et al. [2] find that, in the early 2000s, the increase in activity restrictions imposed on banks led these institutions to take more risks.

\section{CONCLUSION}

The nineties were marked by the succession of financial crises: the Mexican crisis of 1994, the crisis of East Asia, Russia, and Brazil. These crises took place a few years after the financial liberalization, although the latter was seen as an essential condition for economic growth and development. It is important to point out that these crises have cost the liberalized countries dearly. 
The objective is to know whether countries have been able to apply the Basel guidelines, and whether they have been able to reinforce capital regulations and official supervisors after the 1997 crisis. However, some countries have allowed private control of banks in accordance with Basel II Pillar III.

Our results showed that there is a difference between the two sections. The 1997 section presented better results since the crisis of the emerging countries was mainly in the nineties seven. As a result, the only common factors that accounted for the onset of crises for both dates were the law, Z-score, and the percentage of banking system assets in foreign-owned banks.

As for banking regulations, we cannot talk about the absence of the latter but we must point out a weakness of banking supervision that has led these countries to banking crises or international crises.

Our results also show that restrictions on insurance, the financial market, and the real estate sector are unrelated to the outbreak of banking crises in all our estimates. Which leaves us to affirm that a good regulation leads to a banking stability? On the other hand, the regulation on banks' ability to hold and control non-financial firm's increases the fragility of banks in 1997. We can conclude that the banks that diversify their activities will be able to widen their sources of income and become more resistant to shocks. This will have positive effects on the stability of the banking system.

For example, the regulation on the extent to which a bank may hold shares in a non-financial corporation has affected a bank's ability to diversify its sources of revenue. As a result, the absence of diversification has clearly led banks to bank fragility and consequently to a banking crisis. Another interesting observation that confirms the old theories is that an imbalance in the stock of foreign exchange also favors the occurrence of a banking crisis where currency crises favor banking crises.

In conclusion, our results are interesting and could be completed by the study of Tunisian banks after the jasmine revolution. We could deepen the idea of supervision and the controls and regulations imposed by the IMF. From an empirical point of view, we could consider setting up a banking risk management system that complies with international prudential standards.

\section{REFERENCES}

1. Allen, F., Carletti, E., \& Leonello, A. (2011). Deposit insurance and risk taking. Oxford Review of Economic Policy, 27(3), 464-478.

2. Barth, S., Fischer, M., Schmid, R. D., \& Pleiss, J. (2004). The database of epoxide hydrolases and haloalkane dehalogenases: one structure, many functions. Bioinformatics, 20(16), 2845-2847.
3. Angkinand, A. P., Sawangngoenyuang, W., \& Wihlborg, C. (2010). Financial liberalization and banking crises: A cross-country analysis. International Review of Finance, 10(2), 263-292.

4. Assa, H., \& Okhrati, R. (2018). Designing sound deposit insurances. Journal of Computational and Applied Mathematics, 327, 226-242.

5. Anginer, D., Demirguc-Kunt, A., \& Zhu, M. (2012). How does deposit insurance affect bank risk? Evidence from the recent crisis. The World Bank.

6. Kusairi, S., Sanusi, N. A., \& Ismail, A. G. (2018). Dilemma of deposit insurance policy in ASEAN countries: Does it promote banking industry stability or moral hazard?. Borsa Istanbul Review, 18(1), 33-40.

7. Shrieves, R. E., \& Dahl, D. (1992). The relationship between risk and capital in commercial banks. Journal of Banking \& Finance, 16(2), 439457.

8. Mathonnat, C., \& Minea, A. (2018). Financial development and the occurrence of banking crises. Journal of Banking \& Finance, 96, 344-354.

9. Brinkmann, E. J., \& Horvitz, P. M. (1995). Riskbased capital standards and the credit crunch. Journal of Money, Credit and Banking, 27(3), 848-863.

10. Park, J. (2012). Corruption, soundness of the banking sector, and economic growth: A crosscountry study. Journal of international money and Finance, 31(5), 907-929.

11. La Porta, R., Lopez-de-Silanes, F., Shleifer, A., \& Vishny, R. (2000). Investor protection and corporate governance. Journal of financial economics, 58(1-2), 3-27.

12. Love, I., \& Klapper, L. F. (2002). Corporate governance, investor protection, and performance in emerging markets. The World Bank.

13. Cubillas, E., \& González, F. (2014). Financial liberalization and bank risk-taking: International evidence. Journal of Financial Stability, 11, 32-48.

14. Wagster, J. D. (1999). The Basle Accord of 1988 and the international credit crunch of 19891992. Journal of Financial Services Research, 15(2), 123-143.

15. Nouy, D. (2003). L'économie du nouveau dispositif et les conséquences de la nouvelle réglementation. Revue d'économie financière, 97110.

16. Lassoued, N., Sassi, H., \& Attia, M. B. R. (2016). The impact of state and foreign ownership on banking risk: Evidence from the MENA countries. Research in International Business and Finance, 36, 167-178.

17. Baicu, C. G. (2012). Financial crisis, regulation and competition: the Romanian banking experience. Procedia Economics and Finance, 3, 426-431. 
18. Chen, J., \& Zhu, L. (2019). Foreign penetration, competition, and financial freedom: Evidence from the banking industries in emerging markets. Journal of Economics and Business, 102, 26-38.

19. Laeven, L., \& Valencia, F. (2013). The real effects of financial sector interventions during crises. Journal of money, credit and Banking, 45(1), 147-177.

20. Thakor, A. V. (2018). Post-crisis regulatory reform in banking: Address insolvency risk, not illiquidity!. Journal of Financial Stability, 37, 107111.

21. Rhee, D. E., \& Kim, H. (2018). Does income inequality lead to banking crises in developing countries? Empirical evidence from cross-country panel data. Economic Systems, 42(2), 206-218.

22. Demirgüç-Kunt, A., \& Huizinga, H. (1999). Determinants of commercial bank interest margins and profitability: some international evidence. The World Bank Economic Review, 13(2), 379-408.

23. Boyd, J. H., Graham, S. L., \& Hewitt, R. S. (1993). Bank holding company mergers with nonbank financial firms: Effects on the risk of failure. Journal of banking \& finance, 17(1), 43-63.

24. Laeven, L., \& Levine, R. (2007). Is there a diversification discount in financial conglomerates?. Journal of Financial Economics, 85(2), 331-367.

25. Kaminsky, G. L., \& Reinhart, C. M. (1999). The twin crises: the causes of banking and balance-ofpayments problems. American economic review, 89(3), 473-500.

26. Fosu, S., Danso, A., Agyei-Boapeah, H., Ntim, C. G., \& Murinde, V. (2018). How does banking market power affect bank opacity? Evidence from analysts' forecasts. International Review of Financial Analysis, 60, 38-52.

\section{Annexe}

Table-1: List of emerging and developed countries

\begin{tabular}{|c|c|c|}
\hline \multicolumn{3}{|c|}{ Developed countries } \\
\hline Australia & Germany & Netherlands \\
\hline Austria & Gibraltar & New Zealand \\
\hline Belgium & Greece & Portugal \\
\hline Canada & Iceland & Slovenia \\
\hline Cayman Islands & Ireland & Spain \\
\hline Cyprus & Italy & Sweden \\
\hline Denmark & Japan & Switzerland \\
\hline Filand & Liechtenstein & United Kingdom \\
\hline France & Luxembourg & United states \\
\hline \multicolumn{3}{|c|}{ Emerging countries } \\
\hline Argentine & Guyana & Peru \\
\hline Aruba & Honduras & Philippines \\
\hline Bangladesh & Hongray & Poland \\
\hline Belarus & India & Puerto Rico \\
\hline Bhutan & Indonesia & Qatar \\
\hline Bolivia & Israel & Romania \\
\hline Bostawana & Jamaica & Russia \\
\hline Brasil & Jordan & Rwanda \\
\hline Britshvirginislands & Kenya & St kitts \\
\hline Burundi & Korea & Samoa \\
\hline Cambodia & Kuwait & Saudiarabia \\
\hline Chile & Latvia & Seychelles \\
\hline China & Lebanon & Singapore \\
\hline Croatia & Lesotho & Solomon Islands \\
\hline Czechrepublic & Lithania & South africa \\
\hline Egypt & Macau & Siri Lanka \\
\hline El Salvador & Macedonia & Tajikstan \\
\hline Estonia & Malawi & Thailand \\
\hline Gambia & Malaysia & Tonga \\
\hline Ghana & Maldives & Trinidad et Tobago \\
\hline Guatemala & Malta & Turkey \\
\hline Guersney & Mauritius & Turks and caicos \\
\hline Népal & Mexico & Vanuata \\
\hline Nigeria & Moldova & Venezuela \\
\hline Oman & Maroco & Vietnam \\
\hline Panama & Nambia & Zambia \\
\hline
\end{tabular}

